\title{
Endocrine and Metabolic Disorders in Bronchial Carcinoma
}

\author{
J. G. AZZOPARDI,* M.D., M.R.C.PATH. ; E. FREEMAN,† M.R.C.P., M.R.C.P.ED. ; G. POOLE, $\ddagger$ M.B., M.R.C.P.
}

British Medical fournal, 1970, 4, 528-530

\begin{abstract}
Gummary: In an unselected series of 185 patients with histologically confirmed bronchial carcinoma 16 had endocrine disturbances attributable to the tumour (excluding pulmonary osteoarthropathy). Of these, 11 patients had hypercalcaemia; three inappropriate secretion of antidiuretic hormone; one Cushing's disease; three hypertrophic osteoarthropathy; and one gynaecomastia. Cushing's disease and inappropriate antidiuresis are specifically associated with oat-cell tumours, and hypercalcaemia occurs most frequently with squamous carcinoma. A negative correlation exists between gynaecomastia and osteoarthropathy on the one hand and oat-cell carcinoma on the other.
\end{abstract}

\section{Introduction}

Several endocrine syndromes are known to be associated with carcinoma of the bronchus (British Medical fournal, 1968), but unless deliberately sought they may easily be overlooked. The clinical features of hyponatraemia, for example, can be mistakenly attributed to the general ill health associated with carcinomatosis. The frequency with which these syndromes occur is not known as there have been very few large-scale investigations. Carey (1966) found six examples of hypercalcaemia among 100 consecutive cases of bronchial carcinoma, whereas Ross (1966) found only one. Our aim is to present evidence on this point and on the association between particular syndromes and specific tumour types.

\section{Methods}

Between May 1963 and June 1968211 patients with carcinoma of the bronchus were admitted to the wards at Hammersmith Hospital from the chest clinic. All were specifically questioned and examined for clinical evidence of the endocrine anomalies known to be associated with lung tumours, such as Cushing's syndrome, carcinoid syndrome, gynaecomastia, and osteoarthropy. Serum calcium, inorganic phosphate, sodium, potassium, chloride, bicarbonate, and urea were estimated. Further investigations depended on the results of this screening procedure. Symptoms of osteoarthropathy were confirmed by radiology. The histology of all tumours was reviewed and classified by one of us. Tumours originally reported as "undifferentiated" were reexamined and classified into squamous carcinoma, oat-cell carcinoma, or adenocarcinoma; some could not be so classified.

\section{Results}

Carcinoma of the bronchus was confirmed histologically in 185 of the 211 patients $(87.7 \%), 19$ of them (10.3\%) having an endocrine disorder. The numbers and percentages of tumours histologically classified are shown in Table I; the material examined consisted of biopsy specimens, resected specimens, and/or necropsy tissue. The incidence of endocrine syndromes in the 185 patients is shown in Table \footnotetext{
* Reader in Oncology, Royal Postgraduate Medical School of London,

† Medical Registrar, Hammersmith Hospital Chest Clinic, London W.12.

Consultant Chest Physician, Hammersmith Hospital Chest Clinic, and Lecturer in Respiratory Diseases, Royal Postgraduate Medical School of London.
}

II, and includes, for convenience, cases of hypertrophic pulmonary osteoarthropathy, though factors other than endocrine are important in this condition.

The relation between the endocrine syndromes and the histological types of tumour in this serics is shown in Table III. The most common abnormalities were hypercalcaemia and the syndrome of inappropriate secretion of antidiuretic hormone: details of the relevant biochemical data are presented in Tables IV and V. Bone metastases were not shown clinically or radiologically when hypercalcaemia was detected in the patients included in Table IV. Eight of these

TABLE I.-Classification of Tumours

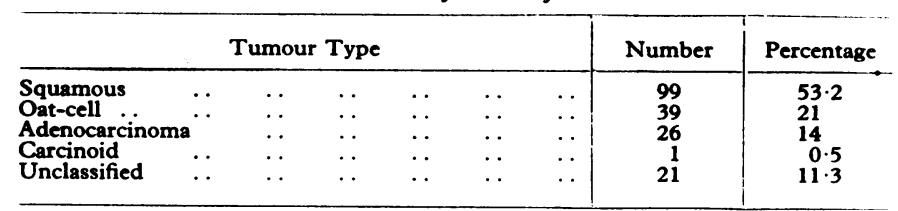

The total of 186 includes one patient with two distinct tumours.

TABLE II.-Frequency of Endocrine Syndromes

\begin{tabular}{|c|c|c|c|c|c|c|c|}
\hline \multicolumn{6}{|c|}{ Endocrine Anomaly } & \multirow{2}{*}{$\begin{array}{c}\text { Number } \\
11 \\
3 \\
1 \\
3 \\
1\end{array}$} & \multirow{2}{*}{$\begin{array}{c}\text { Percentage } \\
5.9 \\
1.6 \\
0.5 \\
1.6 \\
0.5\end{array}$} \\
\hline $\begin{array}{l}\text { Hypercalcaemia . } \\
\text { S.I.A.D.H. } \\
\text { Cushing's disease } \\
\text { H.P.O.A... } \\
\text { Gynaecomastia . . }\end{array}$ & $\begin{array}{l}\cdots \\
\cdots \\
\cdots \\
\cdots\end{array}$ & $\begin{array}{l}\cdots \\
\cdots \\
\cdots \\
\cdots\end{array}$ & $\begin{array}{l}\cdots \\
\cdots \\
\cdots \\
\cdots\end{array}$ & $\begin{array}{l}\cdots \\
\cdots \\
\cdots \\
\cdots\end{array}$ & $\begin{array}{l}\cdots \\
\cdots \\
\cdots \\
\cdots\end{array}$ & & \\
\hline
\end{tabular}

S.I.A.D.H. = Syndrome of inappropriate secretion of antidiuretic hormone. H.P.O.A $=$ Hypertrophic pulmonary osteoarthropathy.

TABLE III.-Relation of Endocrine Syndromes to Different Tumour Types

\begin{tabular}{|c|c|c|c|c|c|}
\hline Tumour Type & $\begin{array}{c}\text { Hyper- } \\
\text { calcaemia }\end{array}$ & S.I.A.D.H. & $\begin{array}{c}\text { Cushing's } \\
\text { Disease }\end{array}$ & H.P.O.A. & $\overline{\text { mastia }}$ \\
\hline \multirow{2}{*}{ 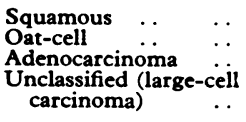 } & $\begin{array}{l}8 \\
1 \\
1\end{array}$ & $\begin{array}{l}1 * \\
2 \\
0\end{array}$ & $\begin{array}{l}0 \\
1 \\
0\end{array}$ & $\begin{array}{l}2 \\
0 \\
1\end{array}$ & $\begin{array}{l}1+ \\
1+ \\
0\end{array}$ \\
\hline & 1 & 0 & 0 & 0 & 0 \\
\hline
\end{tabular}

Necropsy not performed (see text.)

tSame patient with two tumours.

TABLE IV.-The Hypercalcaemias

\begin{tabular}{|c|c|c|c|c|c|c|}
\hline \multicolumn{3}{|l|}{$\begin{array}{l}\text { Case } \\
\text { No. }\end{array}$} & $\underset{(\mathrm{mN} / 1 .)}{\mathrm{Ca}++}$ & $\begin{array}{c}\left.\mathrm{PO}_{4}--\overline{\mathrm{mN}} / \mathrm{I} .\right) \\
\end{array}$ & $\underset{(\mathrm{mN} / 1 .)}{\mathrm{HCO}_{3}-}$ & $\underset{(\mathbf{m N} / 1 .}{\mathbf{K}}$ \\
\hline \multicolumn{3}{|c|}{ Normal: } & $4 \cdot 7-5 \cdot 5$ & $1 \cdot 6-2 \cdot 4$ & $24-30$ & $3 \cdot 8-5 \cdot 2$ \\
\hline 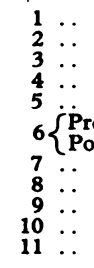 & $\begin{array}{c}\ldots \\
\cdots \\
\cdots \\
\cdots\end{array}$ & $\begin{array}{l}\cdots \\
\because \\
\cdots \\
\cdots\end{array}$ & $\begin{array}{l}6 \cdot 4-8 \cdot 6 \\
5 \cdot 6-6 \cdot 1 \\
5 \cdot 9 \\
6 \cdot 9-9 \cdot 3 \\
7 \cdot 6-9 \cdot 6 \\
6 \cdot 6-7 \cdot 1 \\
4 \cdot 8-5 \cdot 2 \\
6 \cdot 0 \\
6 \cdot 4 \\
5 \cdot 8 \\
7 \cdot 4-8 \cdot 1 \\
6 \cdot 6-7 \cdot 2\end{array}$ & $\begin{array}{l}1 \cdot 8 \\
1 \cdot 6-1 \cdot 8 \\
1 \cdot 9-2 \cdot 0 \\
1 \cdot 3-1 \cdot 7 \\
1 \cdot 7-2 \cdot 0 \\
1 \cdot 3-1 \cdot 5 \\
1 \cdot 8-2 \cdot 1 \\
2 \cdot 0 \\
2 \cdot 1-2 \cdot 2 \\
2 \cdot 1 \\
1 \cdot 7-2 \cdot 5 \\
1 \cdot 2-1 \cdot 6\end{array}$ & $\begin{array}{l}24-32 \\
25-35 \\
25 \\
31-42 \\
32-39 \\
35 \\
29 \\
27 \\
19-31 \\
29-31\end{array}$ & $\begin{array}{l}3 \cdot 8-4 \cdot 7 \\
2 \cdot 7-4 \cdot 6 \\
4 \cdot 4 \\
1 \cdot 6-3 \cdot 8 \\
2 \cdot 7-4 \cdot 0 \\
3 \cdot 6-4 \cdot 1 \\
4 \cdot 0-4 \cdot 9 \\
4 \cdot 3 \\
3 \cdot 9 \\
4 \cdot 2-4 \cdot 8 \\
2 \cdot 8-3 \cdot 5\end{array}$ \\
\hline
\end{tabular}

TABLE V.-The Hyponatraemias

\begin{tabular}{|c|c|c|c|c|c|c|}
\hline & $\begin{array}{c}\text { Serum } \\
\text { Nat+ } \\
(\mathrm{mN} / 1 .)\end{array}$ & $\underset{(\mathrm{mN} / \mathrm{l} .)}{\text { Serum }}$ & $\begin{array}{c}\text { Serum } \\
\text { Urea } \\
\text { (mg./100ml.) }\end{array}$ & $\underset{\substack{\text { Osmo } \\
\text { (mOsr }}}{\text { Serum }}$ & $\begin{array}{l}\text { Urine } \\
\text { olality } \\
\text { n/kg.) }\end{array}$ & $\begin{array}{c}\text { Plasma } \\
\text { Cortisol } \\
(\mu 8 . / 100 \mathrm{ml} .)\end{array}$ \\
\hline Normal: & $136-149$ & $100-107$ & $14-38$ & $\overline{285-295}$ & $600-700$ & $<25$ \\
\hline $\begin{array}{ll}\text { Case } 12 & . . \\
\text { Case } 13 & \ldots \\
\text { Case } 14 & \ldots\end{array}$ & $\begin{array}{l}120-124 \\
124-128 \\
117-120\end{array}$ & $\begin{array}{c}88 \text { and } 88 \\
83-88 \\
83-94\end{array}$ & $\begin{array}{l}27-38 \\
19-40 \\
10-21\end{array}$ & $\begin{array}{c}268-276 \\
260-275 \\
-\end{array}$ & $\begin{array}{c}700-900 \\
630-815 \\
-\end{array}$ & $\begin{array}{l}22 \cdot 5 \\
10 \\
11\end{array}$ \\
\hline
\end{tabular}


patients came to necropsy, and even then only one had scanty bone metastases. These were not considered adequate to explain the gross hypercalcaemia in this patient (Case 5).

\section{Discussion}

If endocrine effects are specifically looked for in an unselected series of patients with bronchial carcinoma the incidence is higher than is currently believed. We found an incidence of $8.5 \%$, excluding cases of hypertrophic pulmonary osteoarthropathy, in which hormonal factors are of uncertain significance; but even this probably underestimates the true incidence, because not all the patients in the series could be followed-up until they died. Probably disorders such as hypercalcaemia sometimes become manifest only when the disease is far advanced and when the resulting symptoms may be mistaken for the non-specific effects of carcinomatosis.

Ross (1966) found two cases of Cushing's syndrome among 100 proved bronchial carcinomata, but our figure of $0.5 \%$ suggests that the incidence may be even lower. Our patient had an oat-cell carcinoma, which conforms to the findings of Azzopardi and Williams (1968) that oat-cell carcinoma and bronchial carcinoid are the only lung tumours as yet proved to cause Cushing's syndrome. One should beware of diagnosing Cushing's syndrome because of the presence of hypokalaemic alkalosis alone. Hypercalcaemia, and perhaps the hypercalcaemia of malignant disease especially, is often associated with hypokalaemic alkalosis (Azzopardi and Whittaker, 1969); though the mechanism is not understood, it appears to be unrelated to adrenocortical activity.

The hyponatraemic syndrome usually attributable to inappropriate antidiuresis occurred in three patients $(1.6 \%)$. In a fourth patient who may have had the syndrome other factors were present that could have accounted for the hyponatraemia. Initially, it was thought that only one of the three had an oat-cell carcinoma, while two had squamous tumours. At necropsy, however, one of the latter had a macroscopically distinct oat-cell carcinoma with metastases, in addition to at least one, possibly two, squamous carcinomas of the bronchus. This illustrates the dangers of drawing conclusions without a thorough necropsy as well as drawing attention to the occurrence of multiple independent primary bronchial carcinomas. In the third patient inappropriate antidiuresis was associated with a squamous carcinoma of the right lung. It is noteworthy, however, that there was no evidence of endocrine disorder before the squamous tumour was resected; the biochemical abnormality was found at follow-up when no radiological evidence of carcinoma could be detected. The patient died shortly afterwards; there was no necropsy. We hesitate to regard the squamous carcinoma as causative of inappropriate antidiuresis especially since no such instance is recorded. It is impossible, for instance, to exclude the coexistence of another tumour.

Hypercalcaemia, on the other hand, is most frequently associated with squamous carcinoma. Eight of our 11 hypercalcaemic patients had squamous tumours, one had an oatcell carcinoma, one an adenocarcinoma, and the last a largecell undifferentiated tumour (unclassified further). Azzopardi and Whittaker (1969), in a study of necropsy material, also found numerous squamous tumours among bronchial carcinomas causing this syndrome, and noted a suggestion of a negative correlation between the syndrome and oat-cell carcinoma. If the seven new cases in this series are added to their collected data only two out of 29 examples of the hypercalcaemic syndrome are attributable to oat-cell carcinoma.

The reported frequency of the hypercalcaemic syndrome has varied from $1 \%$ of 100 (Ross, 1966) to $16 \%$ of 50 cases (Azzopardi and Whittaker, 1969), the incidence in the present series $(5.9 \%)$ falling between the two. The reason for these differing figures is partly inherent in the method of selection. The study of Azzopardi and Whittaker was based on patients investigated until their death in hospital, and this group is likely to include a high incidence of patients with complications requiring hospital investigation. On the other hand, in some cases hypercalcaemia may appear only when the tumour is extensive or late in the course of the illness, so that a series based on findings at the time of the original diagnosis may underestimate the incidence. The disease was thought to be extensive on clinical grounds, at the time hypercalcaemia was discovered, in 9 of our 11 patients. It is of interest that eight of them were hypercalcaemic when first seen.

The reported incidence of hypertrophic pulmonary osteoarthropathy in different series varies between about $2 \%$ and $12 \%$, depending on the type of material studied, the criteria for making a diagnosis of hypertrophic pulmonary osteoarthropathy, and other factors. With the rigid criteria adopted here, only $1.6 \%$ of patients showed this disorder. The nature of the pathological material in our cases (bronchial biopsy in one, sputum cytology in another, and a subcutaneous metastasis in the third) gave no information on tumour site. Two patients had squamous carcinoma and one an adenocarcinoma. Yacoub (1965) had no cases of hypertrophic pulmonary osteoarthropathy in a large series of patients with oat-cell carcinoma, and our scant data on this point are consistent with his findings. Stenseth, Clagett, and Woolner (1967), on the other hand, found an incidence of hypertrophic pulmonary osteoarthropathy with "small-cell carcinoma" of $5 \%$ compared with an incidence of $9.4 \%$ with squamous tumours. It is, however, not clear from the latter's data, drawn from a very large retrospective series, whether the histological diagnosis of tumour type was confirmed at the time of their study. Cases of oat-cell carcinoma with hypertrophic pulmonary osteoarthropathy are certainly rare enough to warrant thorough documentation.

Gynaecomastia, bilateral and confirmed histologically at necropsy, was present in only one patient. Since the gynaecomastia in this case was first detected at necropsy this disorder probably escaped detection in other patients. The patient with gynaecomastia was unusual in having both squamous and oat-cell carcinoma; there was no osteoarthropathy. This "gynaecomastie isolée," as it has been called, has been described with both squamous carcinoma and adenocarcinoma of the bronchus. A chorionic-gonadotrophin-like substance has been identified in tumour tissue: this is believed to cause stimulation of testicular interstitial cells, increased oestrogen secretion, and gynacomastia as a result (Fusco and Rosen, 1966), though Becker et al. (1968) found no evidence of increased oestrogen production. The negative correlation between oat-cell carcinoma and hypertrophic pulmonary osteoarthropathy appears to apply also to gynaecomastia, a point requiring further study.

\section{REFERENCES} Azzopardi, J. G., and Whittaker, R. S. (1969). Fournal of Clinical Pathology,

Azzopardi, J. G., and Williams, E. D. (1968). Cancer (Philadelphia), 22, 274. Becker, K. L., et al. (1968). Fournal of Clinical Endocrinology and Metabolism, 28, 809.

British Medical fournal, 1968, 4, 5.

Carey, V. C. I. (1966). American Review of Respiratory Riseases, 93, 584. Fusco, F. D., and Rosen, S. W. (1966). New England fournal of Medicine,
275, 507.

Ross, E. J. (1966). Proceedings of the Royal Society of Medicine, 59, 335. Stenseth, J. H., Clagett, O. T., and Woolner, L. B. (1967). Diseases of the
Chest, 52, 62. Yacoub, M. H. (1965). Thorax, 20, 537. 